\title{
DETERMINATION OF FLOOD DISCHARGE OF MOYAN WEIR WITH HEC-RAS PROGRAM
}

\author{
ACHMAd SYARIFUdiN* \\ Civil Engineering Faculty, Universitas Bina Darma, Jl. Jend. A.Yani No. 12, South Sumatera, \\ Indonesia \\ *Corresponding author: achmad.syarifudin@binadarma.ac.id \\ (Received: 11 January 2022; Accepted: 16 February 2022; Published on-line: 01 July 2022)
}

\begin{abstract}
This research was conducted to obtain the right discharge plan in the irrigation area with a study of the amount of discharge that can be used upstream of the weir so that the water supply at the intake does not lack water. The Deras II Irrigation Area covering an area of 928 hectares, has 2 weirs as a source of irrigation water, namely the Moyan weir and Aur Weir. The upstream part of the Moyan weir is a sleeping area in the form of a swamp which farmers use to become a paddy field whose source of water comes from the swift river (upstream Moyan weir). With this water uptake, the impact on the flow of water entering the Moyan intake will be reduced, so it needs to be done with the numerical method approach of the HEC-RAS program. The results of this study are graphically depicted at each review station in the channel and the existing discharge obtained from the measurement of the speed with the current meter and water level from each cross-section along the irrigation channel. The simulation results are obtained with the condition of the river crossing, which is not filled, and the discharge is $0.024 \mathrm{~m} 3 / \mathrm{sec}$. The water level at the downstream cross-section is filled as high as $75 \mathrm{~cm}$ with a flow velocity of $0.783 \mathrm{~m} / \mathrm{sec}$, and the water level downstream of the irrigation channel is as high as $40 \mathrm{~cm}$.
\end{abstract}

KEYWORDS: Design discharge; irrigation channel; HEC-RAS program, Water level.

\section{INTRODUCTION}

To realize food sovereignty through Government policy, one of which is to open 1 million hectares of new rice fields outside Java. An irrigation facility with a supporting component is needed to support the opening of new paddy fields [1].

One of the main tasks of the Irrigation Sector, Department of Public Works Cipta Karya, Spatial Planning, and Irrigation of Musi Rawas Regency is to rehabilitate irrigation infrastructure facilities. These efforts can be done by rehabilitating the weir and its irrigation network.

The Deras II Irrigation Area covers an area of 928 ha; this irrigation area has 2 weirs as a source of irrigation water, namely the Moyan weir and Aur Weir built-in 1984/1985 and 1987/1988. Administratively the irrigation area covers the area of Sumber Harta Village, Sumber Harta District.

The source of Moyan weir comes from the Deras River. Originally the upstream part of the Moyan weir was an unused land in the form of a swamp; at this time, farmers reused the swamp into paddy fields whose source of water came from the swift river (upstream Moyan weir). With this water uptake, the flow of water entering the Moyan intake is reduced.

To overcome the problems described above, an activity that produces a water use governance system in the Deras II Irrigation Area and urgent program output is needed. Thus, 
a benefit will be obtained from efforts to overcome the lack of water discharge caused by local natural conditions/conditions and other activities, for example, by increasing the height of the dam or increasing the water supply from the nearest river and spatial planning.

Based on Law no. 7 of 2004 concerning Water Resources, it is necessary to have appropriate activities to manage water use under conditions on the ground and the habits of the local community. In article 51, paragraph (1), it is necessary to immediately disseminate correctly to various groups, especially in regions where water use management is prioritized in prevention activities or non-physical (non-structural) activities besides physical activities. This is a priority approach to water use governance patterns. Therefore, it is necessary to study the amount of discharge that can be used by farmers upstream of the weir so that the water supply at the Moyan intake does not lack water. The water consumption management activity is carried out in the Deras II Irrigation Area (Moyan weir).

\section{MATERIALS AND METHOD}

\subsection{Data Collection}

Includes existing condition data and supporting data collection needed as guidelines for irrigation Operation and Maintenance (OM), which consists of:

1. Data for previous studies.

2. Catchment area topographic map.

3. River buildings and existing infrastructure.

4. Land use around.

5. Administrative boundaries, village/village, and sub-district population.

6. Hydrological data (rainfall stations, rainfall data, water discharge data, and others).

7. Use of river water and water needs.

8. Planting area data, cropping patterns, and growing seasons.

9. Social community.

\subsection{Preliminary Survey and Preliminary Study}

This survey was carried out after studying the maps resulting from the secondary data collection stages. This survey aims to get a clearer picture of the details of damage from existing weirs and estimate the potential for improved dam function for the future. From this survey will be obtained include:

1. Location (administrative, coordinates, river name, and others).

2. Determine the measurement location boundary and topographic reference point

3. Water sources and irrigation water availability

4. Condition of irrigation networks (maps and schemes).

5. Irrigation management status.

6. Water supply, distribution and water supply plan, cropping plans, drying plans, etc.

7. Estimated area of the service area to be irrigated.8) Estimated benefits derived from plans for building a water divider building (tapping building)

8. Institutional irrigation OP.

\subsection{Research Location}

The Location of this research) is located in Sumber Harta District, Musi Rawas Regency (Fig. 1). 


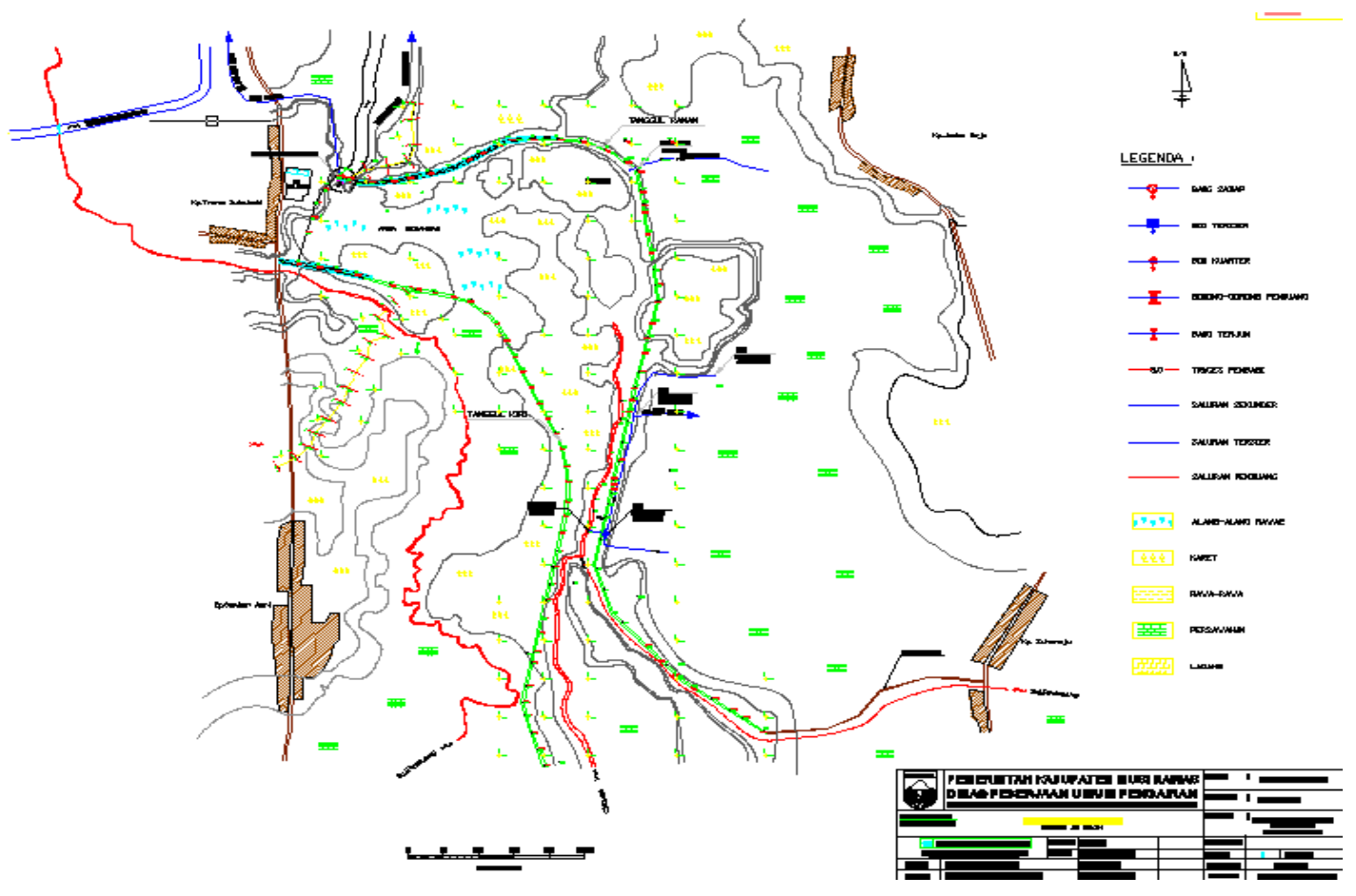

Fig. 1. Research location

\subsection{Geography Position}

Musi Rawas Regency is in the western part of South Sumatra Province and the meeting place of the Musi River upstream with the Rawas River flow. Since the enactment of Law Number 16, the Year 2013 Regarding the Establishment of North Musi Rawas Regency in South Sumatra Province, Musi Rawas Regency has changed both geographical and demographic, geographically located at position $102^{\circ} 07$ ' 00 "- $103^{\circ} 40^{\prime} 10^{\prime \prime}$ East Longitude and $02^{0} 20$ '00 "- $03^{0} 38^{\prime}$ '00" South Latitude. Regional boundaries are as follows:

- Northern Side: Bordering North Musi Rawas Regency.

- Southern Side: Bordering the District of Four Lawang and Lahat Regency.

- Westside: It is bordered by Lubuklinggau City and Bengkulu Province.

- Eastside: It is bordered by Pali Regency and Musi Banyuasin Regency.

The area of Musi Rawas Regency reaches 635,717.15 Ha or $6.39 \%$ of the total area of South Sumatra Province. Musi Rawas Regency ranks fifth largest area in South Sumatra Province. The natural condition of the Musi Rawas Regency consists of potential forests, rice fields, fields, rubber gardens, rock, and other gardens. To the west, there is a narrow lowland bordered by the Bukit Barisan; this plain is getting wider east.

Musi Rawas Regency, many large rivers can be navigated to the upstream. The rivers found in Musi Rawas Regency are the Lakitan River, Kelingi River, Semangus River, and Musi River. In addition to having large rivers, in Musi Rawas Regency, there is a lake, namely Lake Aur, in Sumber Harta District. In addition to its function as a water reservoir, this lake is also a tourism potential for Musi Rawas Regency. 


\subsection{Hydrology and Hydraulic Analysis}

\subsubsection{Regional Description of Planning}

Considering the Moyan weir in Musi Rawas Regency is part of the Deras II Irrigation Area, which, among other things, aims to drain the water discharge by taking into account the following factors [2]:

1. The planning area is classified as a slightly bumpy area.

2. The topography of the relatively flat area and partly marshy is in the form of a basin or depression.

3. The soil is sedimentary soil with poor carrying capacity and a large permeability of $1.09 \times 10-3 \mathrm{~kg} / \mathrm{cm}^{3}$.

\subsubsection{Location and Area of Research}

The research area is located in Musi Rawas Regency, with a measurement range of 2.25 $\mathrm{km}$. Based on the hydrological analysis, a water-use governance design will be conducted.

\subsection{Return Period}

Re-determination period based on how [3]:

\subsubsection{Empirical Method}

Observation data of past events to predict future events with the same magnitude. Chances of extreme events in the " $\mathrm{N}$ " year will be repeated in the next " $\mathrm{n}$ " year expressed by [4]:

$$
P(N, n)=\left(\frac{n}{N}\right)+n
$$

\subsubsection{Risk Analysis}

The risk of failure from the planned building is a risk analysis stated in the equation:

$$
R=1-\left\{1-\left(\frac{1}{T}\right)\right\} n
$$

Where $\mathrm{R}$ is the probability that $\mathrm{Q} \geq \mathrm{Qt}$ happens at least once $\mathrm{n}$ year.

\subsection{Hydrology}

Considering the availability of hydrometric data is not yet available properly, then as a basis for hydrological calculations used rain data. Rain data used is the rain data from the recording of several stations in the planning area and has fairly long data from 1990 to 2008. The average rainfall value is taken from the maximum monthly rainfall data [5].

For estimating rainfall, frequency analysis will be used by reviewing the commonly used distribution [6].

\subsubsection{Estimated Design Rainfall - Over 1 Year}

Estimated rainfall plans are carried out by frequency analysis of annual maximum rainfall data (annual series). There are several statistics in the distribution, which are commonly used in frequency analysis. There are 4 (four) types, namely [7]:

1. Normal

2. Gumbel type I

3. Normal $\log 2$ parameters

4. Pearson type III logs 
Each distribution has unique statistical characteristics. Calculating the statistical parameters of the analyzed data set can estimate which distribution is suitable for that data set. The intended statistical parameters are as follows [8]:

$$
\begin{aligned}
& X=\frac{\sum x_{i}}{n} \\
& S=\sqrt{\frac{\left(x_{i}-x_{r}\right)^{2}}{n-1}} \\
& C_{S}=\frac{n}{(n-1)(n-2) S^{3}} \sum\left(x_{i}-x_{r}\right) 3 \\
& C_{k}=\frac{n}{(n-1)(n-2)(n-3) S^{4}} \sum\left(x_{i}-x_{r}\right) 4
\end{aligned}
$$

Where $\mathrm{X}_{\mathrm{r}}$ is the mean value, $\mathrm{S}$ is the standard deviation, $\mathrm{C}_{\mathrm{s}}$ is the skewness coefficient, $\mathrm{C}_{\mathrm{k}}$ is the Kurtosis coefficient, $x_{i}$ is rainfall data, and $n$ is the number of data [9].

As for the specific statistical nature of each distribution, it can be explained as follows:

1. Normal distribution: $\mathrm{Cs}=0$

Characteristics: $\mathrm{Cs}=0$

Probability $\mathrm{P}(\mathrm{x}-\mathrm{S})=15.87 \%$

$\mathrm{P}(\mathrm{x})=50.00 \%$

$\mathrm{P}(\mathrm{x}+\mathrm{s})=84.14 \%$

The possibility of variates that are at intervals $\mathrm{x}-\mathrm{S}$ and $\mathrm{X}+\mathrm{S}=68.27 \%$ and those that are at intervals $X-2 S$ and $X+2 S=95.44 \%$.

2. Normal log distribution (2 parameters)

Characteristics: $\mathrm{Cs}=3 \mathrm{Cv}$

Cs are always positive

Probability line equation: $x(t)=x+K$

With $x(t)=$ depth of rain with the return period $t$ (years) $K=$ Frequency factor

3. Gumbel type I distribution

Characteristics: $\mathrm{C}_{\mathrm{s}}=1.3960 \mathrm{cv}$

$\mathrm{C}_{\mathrm{k}}=5.4002$

Probability line equation:

$$
X(t)=x+\frac{\sigma}{\sigma n}\left(y-y_{n}\right)
$$

with: $\mathrm{Y}=$ reduced variated

yn and $\delta n=$ The mean value and standard deviation of reduced variated.

4. Log Pearson Distribution type III

The statistical data do not approach the characteristics of the three previous distributions. The rain data is transformed into its natural logarithmic value so that the values of xi change to In xi. Then the average value, standard deviation, and skewness coefficient are calculated as follows [10]: 


$$
\begin{aligned}
& \overline{\ln } x=\frac{\sum_{i=1}^{n} \ln x i}{n} \\
& S=\sqrt{\frac{\sum_{i=1}^{n}(\ln x i-\overline{\ln } x)^{2}}{(n-1)}} \\
& C S=\frac{n}{(n-1)(n-2) S^{3}} \sum_{i=1}^{n}(\ln x i-\overline{\ln } x)^{3}
\end{aligned}
$$

Probability line equation:

$$
\ln x(t)=\overline{\ln } x+K S
$$

$\mathrm{K}$ is the frequency factor obtained from table 3. based on the value of Cs calculated in equation 11 , the depth of rainfall with the return period $t$ is obtained by finding the antilogarithm of the value of $\ln (t)$ [11].

To determine whether the available data is under the chosen theoretical distribution, testing the goodness of fit with Smirnov Kolmogorov and chi-square tests is performed [2].

\subsubsection{Estimated Design Rainfall - Less than 1 Year}

With the frequency analysis above, estimated rainfall plans with a return period of less than $1 \mathrm{t}$ year cannot be done. Determination of the depth of rain with the probability of being equal or done once or several times a year can be done using the approach below [8].

1. Determined length of rain data series (for example, $n$ years).

2. Data in each year is broken down from large to small.

3. The data is taken $(\mathrm{k}+1)$, the largest data in each year, where $\mathrm{k}$ is the number of events equaled or exceeded in the desired year. So that for $n$ years obtained $n \times(k+1)$ data.

4. The new data set is sorted from large to small.

5. Rainfall with probability equaled or exceeded $\mathrm{k}$ times a year is data in order $(\mathrm{n} \times \mathrm{k}+$ 10).

Table 1: Daily Maximum Rainfall Data for Tugumulyo Station

\begin{tabular}{cccccc}
\hline Year & $\begin{array}{c}\text { Rainfall } \\
(\mathbf{X i})\end{array}$ & $(\mathbf{X i -}-\overline{\mathbf{X}})$ & $(\mathbf{X i -} \overline{\mathbf{X}})^{\mathbf{2}}$ & $(\mathbf{X i -} \overline{\mathbf{X}})^{\mathbf{3}}$ & $(\mathbf{X i -} \overline{\mathbf{X}})^{\mathbf{4}}$ \\
\hline 2001 & 260 & 137.667 & 18952.111 & 2609073.963 & 359182515.568 \\
1995 & 143 & 20.667 & 427.111 & 8826.963 & 182423.901 \\
1993 & 139 & 16.667 & 277.778 & 4629.630 & 77160.494 \\
2014 & 132 & 9.667 & 93.444 & 903.296 & 8731.864 \\
1998 & 128 & 5.667 & 32.111 & 181.963 & 1031.123 \\
2013 & 123 & 0.667 & 0.444 & 0.296 & 0.198 \\
2000 & 121 & -1.333 & 1.778 & -2.370 & 3.160 \\
2015 & 120 & -2.333 & 5.444 & -12.704 & 29.642 \\
2016 & 118 & -4.333 & 18.778 & -81.370 & 352.605 \\
\hline
\end{tabular}


https://doi.org/10.51630/ijes.v3i2.52

\begin{tabular}{cccccc}
\hline 2012 & 114 & -8.333 & 69.444 & -578.704 & 4822.531 \\
1999 & 112 & -10.333 & 106.778 & -1103.370 & 11401.494 \\
1991 & 104 & -18.333 & 336.111 & -6162.037 & 112970.679 \\
1996 & 92 & -30.333 & 920.111 & -27910.037 & 846604.457 \\
1997 & 79 & -43.333 & 1877.778 & -81370.370 & 3526049.383 \\
1994 & 50 & -72.333 & 5232.111 & -378456.037 & 27374986.679 \\
\hline Amount & 1835 & 0.000 & 28351.333 & 2127939.111 & 391329083.778 \\
\hline $\bar{X}$ & 122.3333 & & & & \\
\hline $\mathrm{n}$ & 15 &
\end{tabular}

\section{RESULTS AND DISCUSSION}

For case $\mathrm{n}$ of 15: The average sample data $(\overline{\mathrm{X}})$ of 122.333; Standard Deviation (S) of 45,001; Variation Coefficient $\left(\mathrm{C}_{\mathrm{v}}\right)$ of 0.368; Skewness Coefficient $\left(\mathrm{C}_{\mathrm{s}}\right)$ od 1.9245; And coefficient of Kurtosis $\left(\mathrm{C}_{\mathrm{k}}\right)$ of 9.831 .

Table 2: Maximum rainfall data analysis result

\begin{tabular}{cccccc}
\hline Year & $\begin{array}{c}\text { Rainfall } \\
(\mathbf{X})\end{array}$ & $\log \mathbf{X}$ & $(\mathbf{X}-\overline{\mathbf{X}})^{2}$ & $(\mathbf{X}-\overline{\mathbf{X}})^{3}$ & $(\mathbf{X}-\overline{\mathbf{X}})^{4}$ \\
\hline 2001 & 260 & 2.415 & 0.124 & 0.043520 & 0,015308 \\
1995 & 143 & 2.155 & 0.008 & 0.000781 & 0,000072 \\
1993 & 139 & 2.143 & 0.006 & 0.000508 & 0,000041 \\
2014 & 132 & 2.121 & 0.003 & 0.000189 & 0,000011 \\
1998 & 128 & 2.107 & 0.002 & 0.000085 & 0,000004 \\
2013 & 123 & 2.090 & 0.001 & 0.000019 & 0,000001 \\
2000 & 121 & 2.083 & 0.000 & 0.000007 & 0,000000 \\
2015 & 120 & 2.079 & 0.000 & 0.000004 & 0,000000 \\
2016 & 118 & 2.072 & 0.000 & 0.000001 & 0,000000 \\
2012 & 114 & 2.057 & 0.000 & 0.000000 & 0,000000 \\
1999 & 112 & 2.049 & 0.000 & -0.000003 & 0,000000 \\
1991 & 104 & 2.017 & 0.002 & -0.000099 & 0,000005 \\
1996 & 92 & 1.964 & 0.010 & -0.000983 & 0,000098 \\
1997 & 79 & 1.898 & 0.027 & -0.004541 & 0,000752 \\
1994 & 50 & 1.699 & 0.133 & -0.048331 & 0,017605 \\
\hline Amount of & 15 & 30.948 & 0.318 & -0.008843 & 0,016290 \\
\hline data & & & & \\
\hline Statistical parametric: & & 2.063 & Cs & -0.2133 & \\
\hline \multicolumn{2}{c}{ Average } & & Ck & 3.4689 & \\
\hline Standard of deviation & 0,151 &
\end{tabular}

Table 3: Data Distribution Requirements Testing for Using Frequency Analysis

\begin{tabular}{ccrc}
\hline Distribution Type & Terms & Calculation & Conclusion \\
\hline \multirow{2}{*}{ Normal } & $\mathrm{Cs} \approx 0$ & $\mathrm{Cs}=1.9245$ & \multirow{2}{*}{ No, fulfill } \\
& $\mathrm{Ck} \approx 3$ & $\mathrm{Ck}=9.831$ & \\
& $\mathrm{Cs}=1.1396$ & $\mathrm{Cs}=1.9245$ & No, fulfill \\
Gumbel & $\mathrm{Ck}=5.4002$ & $\mathrm{Ck}=9.831$ & No, fulfill
\end{tabular}




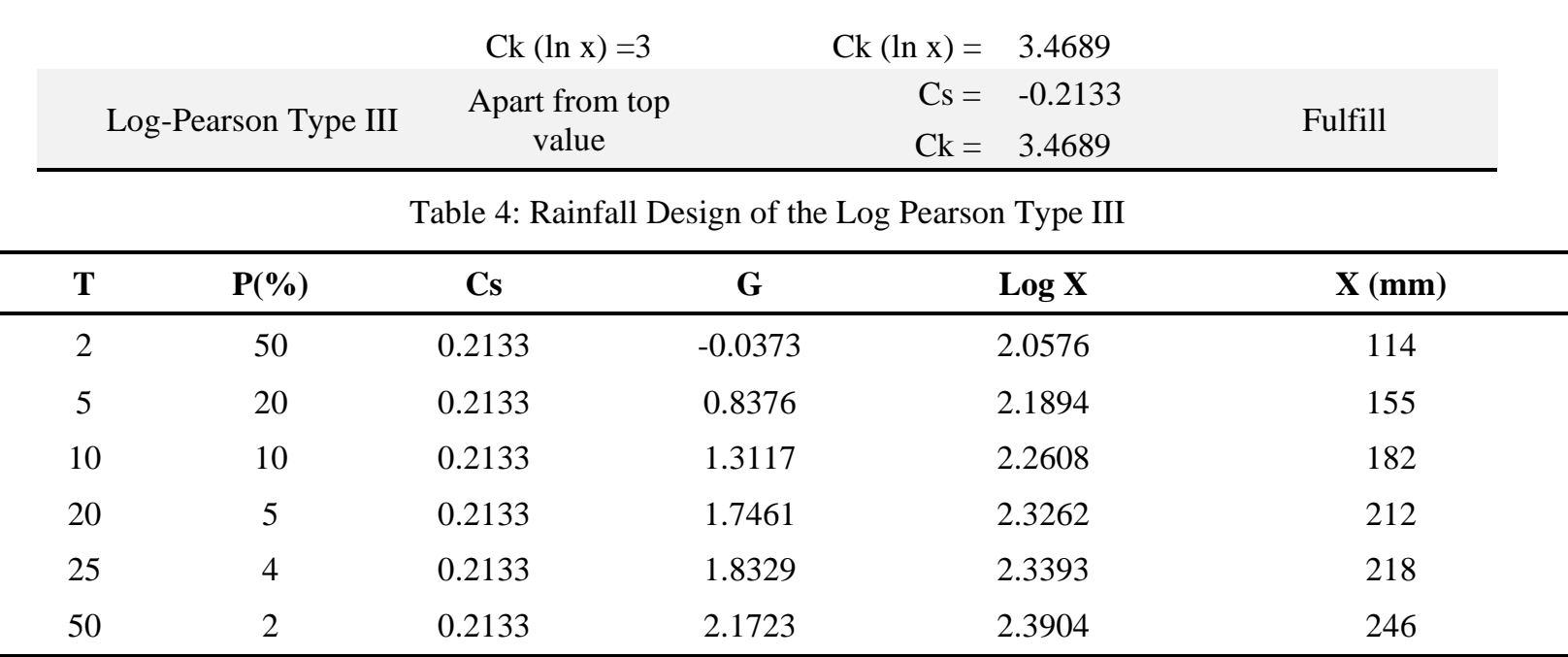

\subsection{Concentration Time $\left(t_{c}\right)$}

Several formulas are used, namely Kraven, Rhiza, and Kirpich, to calculate the concentration-time $(\mathrm{tc})$.

\subsubsection{Kraven Formula}

In addition to the above methods to calculate concentration-time the following formula can be used:

$$
t_{c}=L / W
$$

where $t_{c}$ is flood concentration-time $(\mathrm{dt})$, and $\mathrm{L}$ is the length of the main channels/river $(\mathrm{m})$.

Tabel 5: Hubungan antara slope (S) and Velocity (V)

\begin{tabular}{lccc}
\hline Slope (S) & $>1 / 100$ & $1 / 100-1 / 200$ & $<1 / 200$ \\
\hline Velocity $(W)$ & $3.5 \mathrm{~m} / \mathrm{sec}$ & $3.0 \mathrm{~m} / \mathrm{sec}$ & $2.1 \mathrm{~m} / \mathrm{sec}$ \\
\hline
\end{tabular}

\subsubsection{Rhiza Formula}

$$
W=72 S^{0.6}
$$

where $t_{c}$ is the time of flood concentration (hour), $\mathrm{W}$ is flooding velocity ( $\mathrm{km} /$ hour), $\mathrm{S}$ is average river slope, and $\mathrm{L}$ is river length $(\mathrm{km})$.

\subsubsection{Kirpich Formula}

$$
t_{c}=0.00013 L^{0.77} S^{-0,383}
$$

where $t_{c}$ is the flood of time concentration (hour), $\mathrm{S}$ is the average slope of the main river, $\mathrm{L}$ is the length of the main river (feet); 1 foot $=0.304 \mathrm{~m}$.

The Kirpich formula obtains the concentration-time $(\mathrm{tc})=0.824$ minutes.

\subsection{Rain Intensity}

To determine the amount of rainfall intensity from the amount of rainfall used the formula:

\subsubsection{Ishiguro}

$$
I=\left(\frac{R}{t}\right)\left(\frac{t}{24}\right) k
$$


where $\mathrm{I}$ is average rainfall intensity ( $\mathrm{mm} /$ hour) during $\mathrm{t}, \mathrm{R}$ is daily rainfall $(\mathrm{mm}), \mathrm{t}$ is the duration of rain (hours), and $\mathrm{k}$ is magnitude constant (Takashi) $\mathrm{k}=1 / 3 ;$ (Ito): $1 / 2$.

\subsubsection{Mononobe Formula}

$$
I=\left(\frac{R}{24}\right)\left(\frac{24}{t c}\right)^{2 / 3}
$$

$t$ is equated with a time of $t_{c}$ concentration to calculate the peak flood flow. The two formulas above are suitable for irrigation $>100 \mathrm{~km}^{2}$.

By using the Mononobe formula and rainfall design with the Pearson Log Log Distribution, the rainfall intensity is as shown in Table 6:

Table 6: Rainfall intensity

\begin{tabular}{ccc}
\hline $\mathbf{T r}($ year) & $\mathbf{R}_{\mathbf{2 4}}(\mathbf{m m})$ & $\mathbf{I}(\mathbf{m m} / \mathbf{h o u r})$ \\
\hline 5 & 114 & 45.0343 \\
10 & 155 & 60.9973 \\
25 & 182 & 71.8987 \\
50 & 212 & 83.5867 \\
100 & 218 & 86.1431 \\
\hline
\end{tabular}

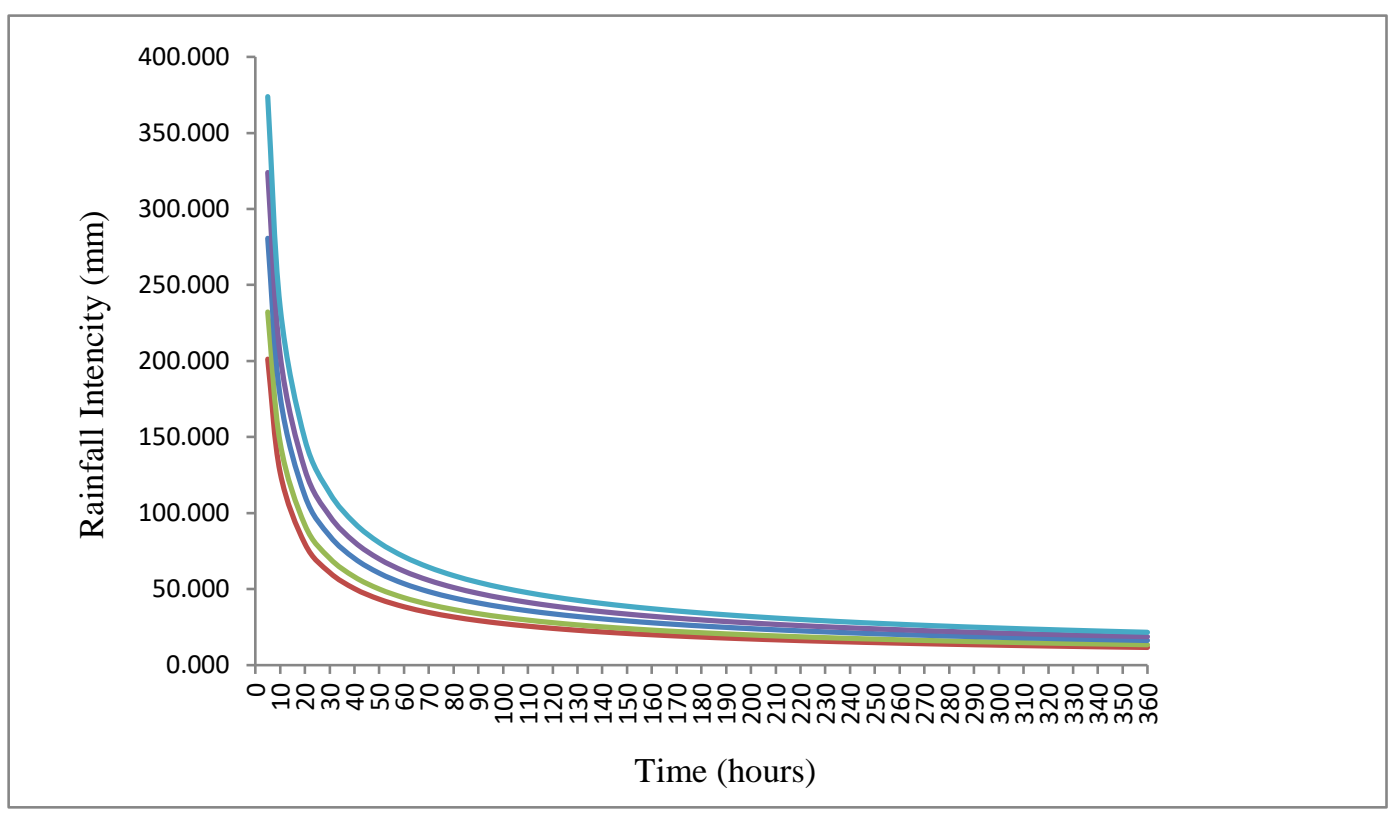

Fig. 2. Intensity Duration Frequency (IDF) curve

\subsubsection{Hydrodynamic Modeling Analysis}

Hydrodynamic modeling results are water level elevation, speed, and several other hydraulic parameters. By doing this hydrodynamic modeling, the water level in each channel segment will be known so that segments that are not filled with water or overflow will be known.

With the knowledge of segments experiencing water shortages, the next step will be able to be carried out, either by making reservoirs or by making channel improvements. 
Hydrodynamic modeling can also create plans/plans combined with control structures such as flood pumps and flood gates. Hydrodynamic modeling with HEC-RAS can also compare plans between existing and design conditions so that the design effect on changes in water level will be known.

In this existing condition modeling, simulation is performed by not inputting from the source; this is intended to check whether the existing system can accommodate the burden of its watershed. The results of modeling the existing debit conditions and plan simulation conditions can be seen in Fig. 3.

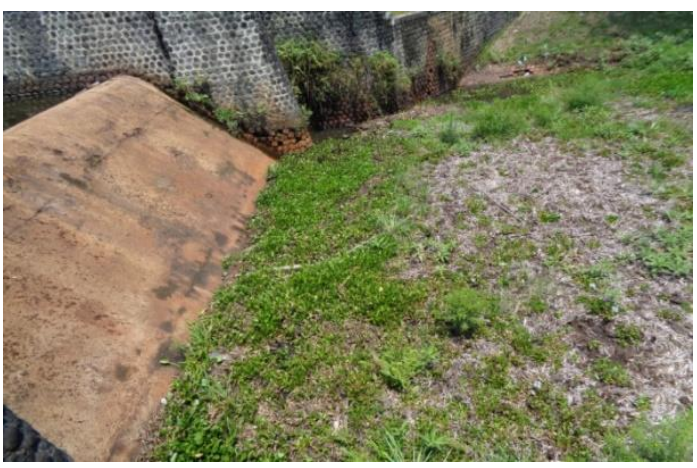

(a)

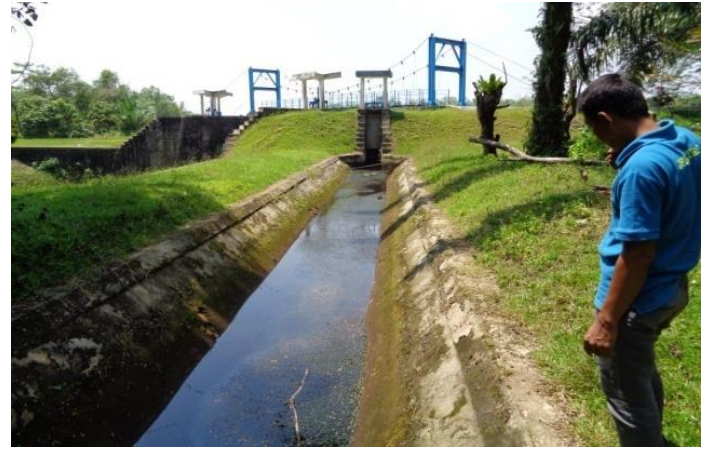

(b)

Fig. 3. (a) Upstream of Moyan weir; (b). Downstream and water level of Moyan weir

\subsection{HEC-RAS Program}

The HEC-RAS program is software used to analyze discharge (Fig. 4).

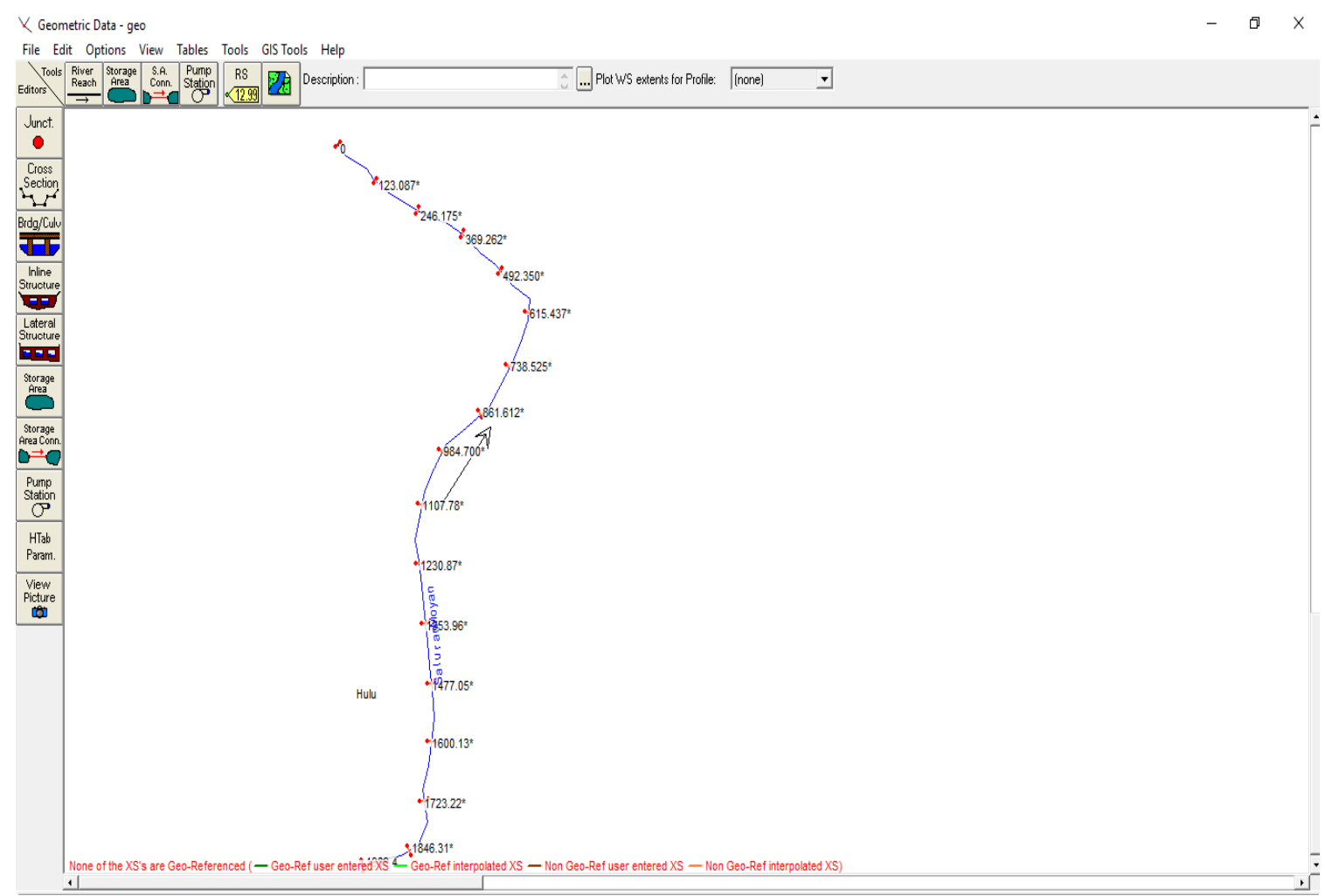

Fig. 4. Moyan Irrigation Geometry Menu 
Existing discharge is obtained from measuring the speed with the current meter and water level from the bottom of the irrigation channel [12].

- Obtained a discharge of $0.024 \mathrm{~m}^{3} / \mathrm{sec}$

- The cross-section condition in the downstream river is not filled with water

- The planned discharge is $1 \mathrm{~m}^{3} / \mathrm{sec}$

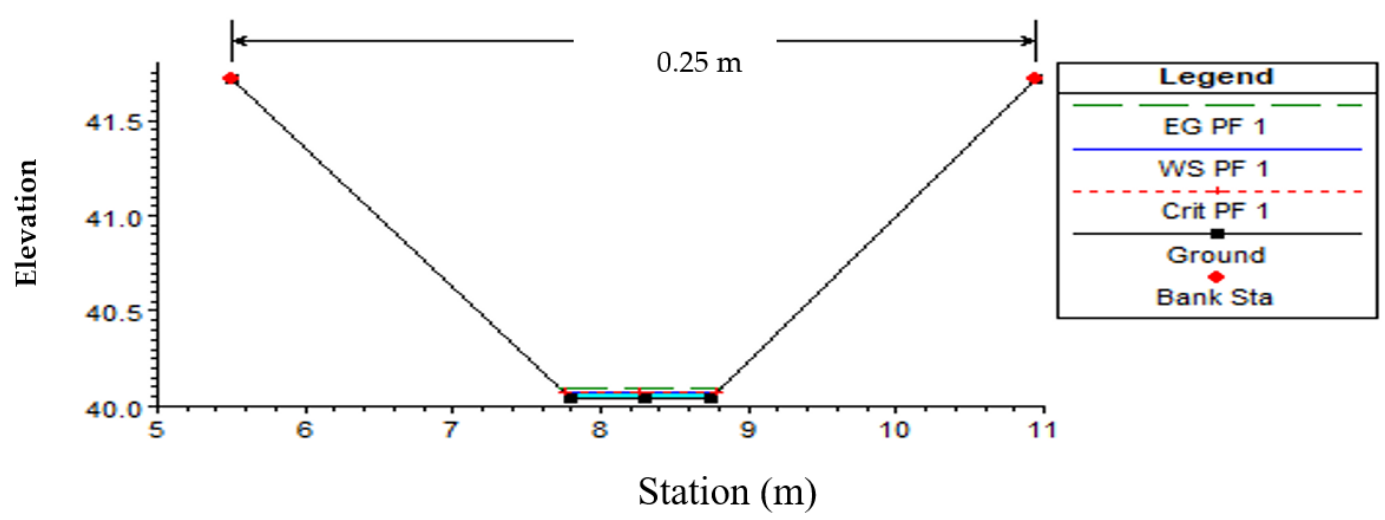

Fig. 5. River cross-section downstream with existing discharge

Fig. 5 shows river cross-section downstream with existing discharge $0.024 \mathrm{~m}^{3} / \mathrm{sec}$ produces water height as high as $8 \mathrm{~cm}$.

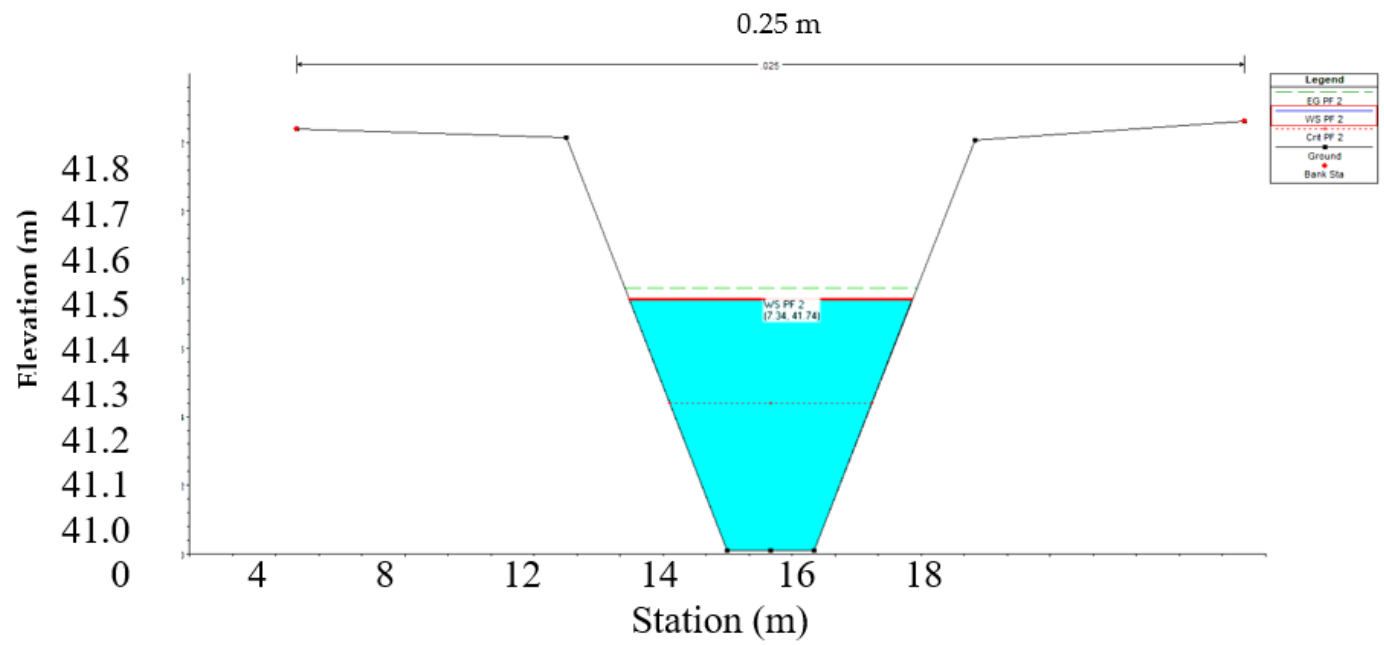

Fig. 6. River cross-section upstream with planned discharge

Fig. 6 shows river cross-section upstream with planned discharge $1 \mathrm{~m}^{3} / \mathrm{sec}$ produces a height of $41.44 \mathrm{~cm}$. 


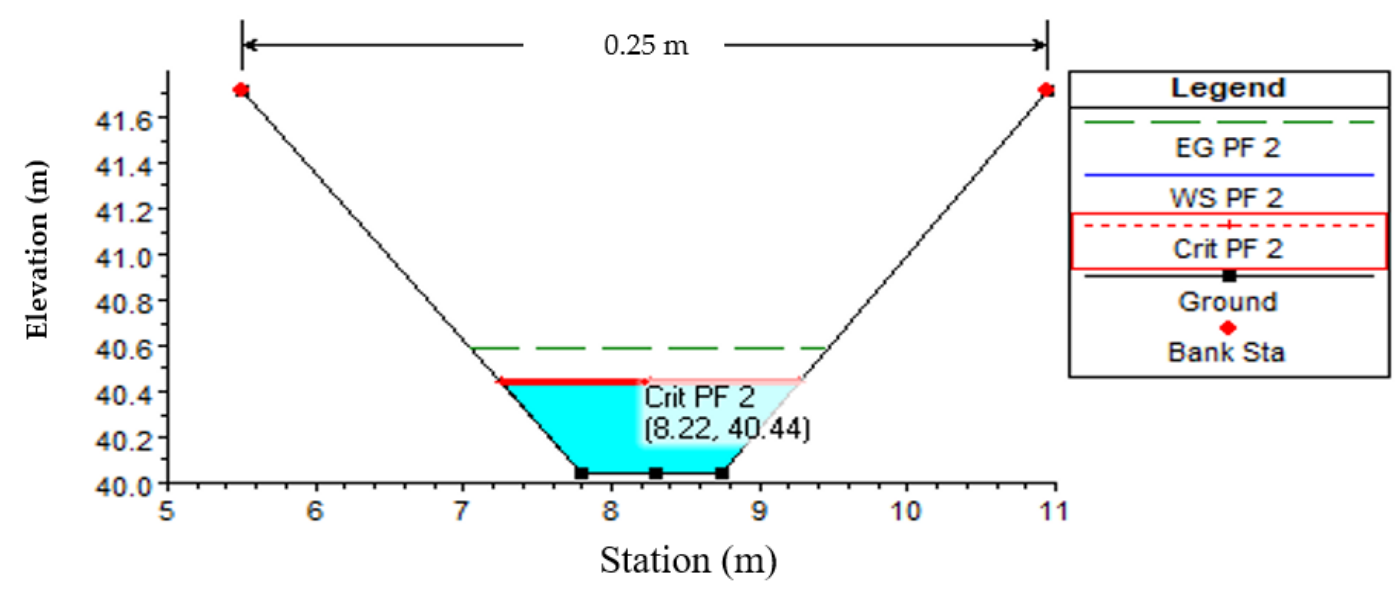

Fig. 7. River cross-section downstream with planned discharge

Fig. 7 shows river cross-section downstream with planned discharge $1 \mathrm{~m}^{3} / \mathrm{sec}$ produces water height as high as $40.44 \mathrm{~cm}$.

\section{CONCLUSION}

The results of this study are graphically depicted at each review station in the channel and the existing discharge obtained from the measurement of the speed with the current meter and water level from each cross-section along the irrigation channel. So can it be concluded that:

- At the Location of the main channel upstream with a discharge of $1 \mathrm{~m}^{3} / \mathrm{sec}$, there was an increase in the water level of $0.415 \mathrm{~m}$, so that the irrigation canal in the Deras II irrigation area could not supply the water demand due to the lack of water flow at the Moyan weir.

- In the downstream area with a discharge of $0.024 \mathrm{~m} 3 / \mathrm{sec}$ only produces the highest water level of $0.08 \mathrm{~m}$ so that the flow conditions in the main channel cannot irrigate the rice fields in the Deras II irrigation area.

- The water level at the downstream cross-section is filled as high as $75 \mathrm{~cm}$ with a flow velocity of $0.783 \mathrm{~m} / \mathrm{sec}$, and the water level downstream of the irrigation channel is as high as $0.40 \mathrm{~m}$.

\section{ACKNOWLEDGEMENT}

Thanks to Universitas Bina Darma for the facilities for this research.

\section{REFERENCES}

[1] F. Aureli and P. Mignosa, "Comparison between experimental and numerical results of 2D flows due to levee-breaking," in Proceedings of the Congress-International Association for Hydraulic Research, 2001, pp. 252-258.

[2] C. Sucipta, H. Wibowo, and D. Gunarto, "Analysis of river geometry on flow discharge in alluvial channels." JeLAST, 2019.

[3] D. Daoed, B. Rusman, B. Istijono, A. Hakam, and M. Syukur, "Evaluation of drought vulnerability on watersheds in West Sumatera Province by using Cropwat-8 and GIS," Int. J. Adv. Sci. Eng. Inf. Technol., vol. 8, no. 6, pp. 2443-2449, 2018.

[4] A. Syarifudin and D. Sartika, "A Scouring Patterns Around Pillars of Sekanak River Bridge," in Journal of Physics: Conference Series, 2019, vol. 1167, no. 1, p. 12019.

[5] M. S. Yalin, Theory of hydraulic models. Macmillan International Higher Education, 1971.

[6] A. K. Chakraborti, "Strategies for Watershed Management planning using remote sensing technique," J. Indian Soc. Remote Sens., vol. 21, no. 2, pp. 87-97, 1993. 
[7] C. Poleto and R. Tassi, "Sustainable urban drainage systems," Drain. Syst., pp. 55-72, 2012.

[8] M. Islam, K. Okubo, Y. Muramoto, and H. Morikawa, "Experimental Study on Sedimentation over the Floodplain due to River Embankment Failure," Bull. Disaster Prev. Res. Inst., vol. 44, no. 2, pp. 69-92, 1994.

[9] A. Syarifudin and H. R. Destania, "IDF Curve Patterns for Flood Control of Air Lakitan river of Musi Rawas Regency," in IOP Conference Series: Earth and Environmental Science, 2020, vol. 448, no. 1 , p. 12054.

[10] C. Ikhsan, "The effect of variations in flow rate on the bottom of an open channel with uniform flow," Civ. Eng. Media, 2017.

[11] V. Te Chow, Applied hydrology. Tata McGraw-Hill Education, 2010.

[12] G. A. M. S. Adjinacou, "Flood Modeling and Floodplain Mapping Based on Geographical Information System (GIS) and HEC-RAS in Oued Fez Watershed (Morocco)." 2016. 